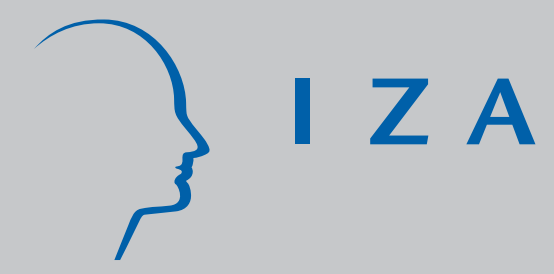

IZADP No. 1008

Labour Income Uncertainty, Risk Aversion and Home Ownership

Luis Diaz-Serrano

February 2004 


\title{
Labour Income Uncertainty, Risk Aversion and Home Ownership
}

\author{
Luis Diaz-Serrano \\ National University of Ireland Maynooth, \\ CREB and IZA Bonn
}

Discussion Paper No. 1008

February 2004

\author{
IZA \\ P.O. Box 7240 \\ 53072 Bonn \\ Germany
}

Phone: +49-228-3894-0

Fax: +49-228-3894-180

Email: iza@iza.org

\begin{abstract}
Any opinions expressed here are those of the author(s) and not those of the institute. Research disseminated by IZA may include views on policy, but the institute itself takes no institutional policy positions.

The Institute for the Study of Labor (IZA) in Bonn is a local and virtual international research center and a place of communication between science, politics and business. IZA is an independent nonprofit company supported by Deutsche Post World Net. The center is associated with the University of Bonn and offers a stimulating research environment through its research networks, research support, and visitors and doctoral programs. IZA engages in (i) original and internationally competitive research in all fields of labor economics, (ii) development of policy concepts, and (iii) dissemination of research results and concepts to the interested public.
\end{abstract}

IZA Discussion Papers often represent preliminary work and are circulated to encourage discussion. Citation of such a paper should account for its provisional character. A revised version may be available on the IZA website (www.iza.org) or directly from the author. 
IZA Discussion Paper No. 1008

February 2004

\title{
ABSTRACT \\ Labour Income Uncertainty, Risk Aversion and Home Ownership*
}

In this paper we investigate the effect of labour income uncertainty on the probability of homeownership in Germany and Spain. This study is motivated by two facts. Firstly, theoretical models tend to provide ambiguous results in this issue. Secondly, there is limited previous empirical evidence and the existing focuses exclusively on the US housing market. We claim that more international evidence is necessary in order to disentangle this puzzle. We develop a simple theoretical formula that highlights the pivotal role of risk attitudes in the housing tenure decisions that also allow us to introduce the concept of "skewness affection" as a relevant phenomenon. To carry out this test we propose an income uncertainty measure based on panel data labour income equations. We observe that households facing increasing income uncertainty display preference for renting while those located in a positively skewed income distribution show a greater propensity for homeownership. Income uncertainty analysis in housing decisions has important implications for the design of public housing policies and also for the design of private mortgage insurance products.

JEL Classification: D1, R0, J0

Keywords: risk aversion, skewness affection, homeownership, earnings uncertainty, transitory shocks in income, credit constraints

\author{
Luis Diaz-Serrano \\ Department of Economics \\ National University of Ireland \\ Maynooth, Co. Kildare \\ Ireland \\ Tel.: +35317083728 \\ Fax: +35317083934 \\ Email: luis.diaz@may.ie
}

\footnotetext{
* Comments from Donal O’Neil, Alexandrina P. Stoyanova and Olive Sweetman are gratefully acknowledged.
} 


\section{Introduction}

The determinants of the households' housing tenure choice have been extensively analyzed in the economic literature. Among these determinants, from a theoretical point of view, uncertainties faced by the households during the planning period have received considerable attention. It is well known that housing is a consumption good, for which the amount purchased cannot be easily altered in response to fluctuations in income. As a consequence of this lack of flexibility in the response to income shocks, uncertainty in future income turns out to be one of the most relevant variable in the decision of homeownership. On one hand, borrowers facing greater income uncertainty may suffer severe restrictions to access to the mortgage market. On the other hand, even if they access to the credit market, it could be expected that risk-averse households will try to avoid mortgage downpayments. There are two main sources of labour income uncertainty: unemployment and fluctuations in income due to market forces. While these uncertainties are usually accounted for in most of the theoretical models, there are hardly any empirical tests.

While theoretical studies tend to provide ambiguous predictions about the effect of income uncertainty on the housing tenure decision, the limited empirical evidence using US data, suggests that this effect is negative. However, empirical evidence based on one country only is not sufficient to disentangle the puzzle. First of all, both renting and property housing markets do not behave identically in all developed economies. Consequently, when taking their housing decisions, households face different institutional settings (housing, credit and labour market) in each country. These institutional differentials may generate not only different attitudes towards risk, but also differences in the individuals' perception of risk in itself, i.e. what is perceived as risky in one country is not necessarily perceived as risky in another country. 
The existing studies of the impact of income uncertainty on the probability of homeownership focus on the variance of future expected income ${ }^{1}$. In this paper, we question whether the single use of the variance is enough to draw individuals' risk attitudes. Some recent labour economic literature (see e.g. Hartog and Vijverberg 2002 or Diaz-Serrano et al. 2003) shows that individuals appreciate positively skewed income distributions, even if they offer a smaller mean. This behavior is due to the fact that in these income distributions the chances of reaching high incomes are smaller, but the probability of a big loss is also smaller than in a more symmetric income distribution. In other words, great deviations from the mean are less likely in a more positively skewed distribution. This phenomenon is called "skewness affection".

The hypothesis exposed above is supported by prospect theory (Kahneman and Tversky, 1979, 1991), which states that the individual's disutility caused by a loss is greater than the utility caused by a gain. According to this reasoning, risk-averse households would feel safer in a positively skewed income distribution than in a symmetric one, even if the more skewed distribution offers a smaller mean. Our conjecture is that risk-averse households exhibiting also "skewness affection" are more likely to purchase their dwelling, since their expectation of a mortgage downpayment is smaller. Hence, we consider that a suitable income uncertainty analysis of the housing tenure choices should account for this effect. In order to capture this behavior, besides using the first two moments of the income distribution (mean and variance), we propose to expand uncertainty analysis on tenure decisions up to the third moment (skewness). We derive this result from a simple theoretical formula and we test it empirically.

We contribute to the existing literature in two ways. Firstly, we provide international evidence about the effect of income uncertainty on the probability of homeownership, which can be compared with the limited existing previous evidence from the US. Secondly, by testing

\footnotetext{
${ }^{1}$ This literature will be reviewed in the next section.
} 
whether "skewness-affection" is a relevant phenomenon we shed some light in the understanding of how homeownership is planed and achieved by the households. To do so, we estimate a housing tenure choice model for Germany and Spain using different measures of income risk. The reason we choose these two countries for the comparative analysis is based on the fact that they represent the two opposite extremes in terms of labour, credit and housing market performance among the EU countries.

Understanding to what extent income (un)certainty, via borrowers' risk-aversion or lending constraints, is a barrier to homeownership has important implications for the design of public housing policies and also in the design of private mortgage insurance products. On one hand, we ask whether public institutions should subsidize households facing borrowing constraints or under a mortgage downpayment risk. And on the other hand, whether the existing private mortgage payment insurance market is efficient in first, covering the main households' income risks, and second, offering affordable products to the households who face high rates of income risk

The remainder of the paper is structured as follows. Section 2 summarizes the existing literature. In section 3 we briefly overview the institutional context in Germany and Spain. In section 4 we present the theoretical framework used as baseline for our empirical estimation. In section 5 we expose the empirical strategy. The data used is described in section 6 . Section 7 reports the empirical results. Finally, section 8 summarizes and concludes.

\section{Literature review}

There exist a vast literature that considers uncertainty in the relevant variables determining the probability of homeownership. Uncertainties in house prices, in future interest rates, in family composition, or in household income is the main focus of this literature. 
Ioannides (1979) finds theoretical support to the negative relationship between uncertainty in housing prices and the propensity to own for risk-averse households. Henderson and Ioannides (1983) introduce randomness in the capital gains or loses generated by the investment in housing. In their theoretical model they predict that if households can invest in the capital market at a fixed rate, renting becomes more attractive than owning. Using macrodata Rosen et al. (1984) show that increasing uncertainty in the relative price of housing property with respect to the renting costs reduces the share of homeowners in the US. In Neuteboom (2003) a comparison of the costs and risks of mortgages for owner-occupiers is offered. He uses the loan-to-income and loanto-value ratios to show risks faced by households in the mortgage market among a selected group of EU countries. He shows that the risks faced by households among these countries differ markedly.

The studies analyzing the effect of income uncertainty on the probability of homeownership are mainly theoretical. DeSalvo and Eeckhoudt (1982) found that the probability of unemployment exerts a negative effect on the homeownership decisions. $\mathrm{Fu}(1995)$ states that under the presence of liquidity constraints the theoretical relationship between income uncertainty and housing tenure is ambiguous. Turnbull et al. (1991) also observe an ambiguous relationship and point out that labour income uncertainty could have a non-negative effect if expected labour income embodies a compensating wage differentials for income risk ${ }^{2}$. Chung and Haurin (2002) specify a theoretical model that also provides ambiguous results. However their simulation study shows that uncertainty in future changes in the influential variables would make households rent. Haurin and Gill (1987), Haurin (1991) and Robst et al. (1999) find empirical

\footnotetext{
${ }^{2}$ The existence of compensating wage differentials for income risk is well documented in the labor economics literature (e.g. King, 1974 and McGoldrick, 1995, for the US, Hartog et al., 2003, for Spain, Germany, The Netherlands and Portugal, and Diaz-Serrano et al., 2003, for Denmark). Al these works provide empirical evidence that reinforces the ambiguity in the relationship between income uncertainty and home ownership derived from their theoretical model.
} 
evidence that housing consumption and the probability of homeownership in the US fall when income risk increases.

The studies analyzing the effect of price uncertainty on homeownership, both theoretical and empirical in nature, reveal a clear negative effect in this relationship. However, as we show above, studies on the effect of income uncertainty on the probability of homeownership, that we are interested in, tend to display ambiguous results. Moreover, although unequivocal, empirical evidence is still very limited on focuses exclusively on the US housing market. We find this is a strong motivation for the present study.

\section{The institutional context in Germany and Spain}

\subsection{The housing market}

The German housing market is characterized by the largest private rental sector among the EU countries (see table 1). The percentage of rented dwellings was about $58 \%$ in 1995 and $57 \%$ in 1999 . The German housing legislation has historically supported the design of attractive policies to promote the renting market. Private landlords enjoy generous tax incentives if they offer their properties in the private rental sector, and can receive subsidized loans if they do so in the social rental sector. Local authorities also provide an important amount of urban land for constructing small social rented flats for the youngest and less favored population. This promotion of the rental market is combined with policies that regulate rental prices. Between 1995 and 1999 the housing cost index for privately rented dwellings increased by around 7\% only. This scenario explains why in Germany the housing rental market is a strong alternative to homeownership. The efficient management of the rental market is translated into stable property

prices. As a consequence is not surprising that the ratio of renters to owner-occupiers remains stable over time. 
Contrary to Germany, the Spanish housing market displays the highest level of imbalance between tenures among the EU countries. The Spanish rental sector is the smallest in Europe (see table 1). In 1995 , only $14 \%$ of the dwelling stock was rented, and this percentage fell to $11 \%$ in 1999. Unlike Germany, in the last decades, Spanish housing policies have been exclusively addressed to promote homeownership. Neither the supply nor the demand in the rental market has been encouraged in any way. Moreover, the existing $15 \%$ personal income tax-relief of the household's renting costs was abolished with the 1998 Personal Income Tax Reform. As a result of the lack of incentives for landlords to rent Spain reports the second highest dwelling vacancy rate after Greece, slightly above $20 \%$. These inefficiencies in the Spanish housing market have also lead to a dramatic increase in rental prices, between 1995 and 1999 the rent index of private rental dwellings has risen by $24 \%$. In Spain the lack of supply and its low quality, added to the high costs, means that young households prefer to be owner-occupiers than renters, facing an aggressively high degree of indebtedness, even in the beginning of their working careers when their labour income may not be very stable. This scenario partially explains why the propensity to own is so high in Spain.

Insert table 1 here

\subsection{The credit market}

During the 1990s, decreasing interest rates and a high competition among lending institutions strongly relaxed the accessibility to the mortgage market in Spain. The 10-15 years of mortgage payment period was extended to $25-30$ years, and the amount borrowed covering $80 \%$ of the value of the dwelling purchased was augmented to above $100 \%$, covering the value of the dwelling, the derived taxes, and the transaction costs. The average pending time between the 
demand and the concession of a mortgage was reduced from 3-6 months in the early 1990s to one week in 2000. The unique requirement the Spanish credit institutions impose on their borrowers is that they have an employment. The purchased dwelling serves by itself as a guarantee.

These practices in the Spanish mortgage market give to credit impaired households access to a mortgage loan. Although this is a positive policy, there is no public provision of default mortgage protection, and private mortgage insurance products are neither affordable for those most at risk nor they offer a wide cover of the risks. Hence, most of these borrowers have a high probability of a mortgage downpayment if they experience a negative shock in income. Such strong relaxation in the accessibility to the credit market partially explains the "boom" in the Spanish housing market, the second greatest after Ireland among EU countries during the late 1990s.

On the contrary, the German mortgage market is generally very conservative. The borrower still remains liable and the lender has recourse to other assets of the borrower, including future earnings. This allows the lender legal recourse to a proportion of the borrower's salary and other income. The ability to seize a portion of the borrower's earnings from his employer acts as a strong disincentive for those households with a relatively high probability of default. Given that there is no "exit" option, German borrowers are generally more reluctant to assume and aggressively high levels of indebtedness (in contrast with the Spanish ones). For instance, between 1994 and 1996 the percentage of households that experienced a mortgage downpayment changed from 0.8 to $0.5 \%$ in Germany, whereas in Spain these numbers moved from 8.2 to $5.6 \%$.

\subsection{The labour market}

The poor performance of the Spanish housing market during the 1990s, in contrast with the German one, also coincides with a poor performance of the Spanish labour market. Although 
the unemployment rate has fallen from $23 \%$ to $15 \%$ between 1995 and 1999, this figure still remains the highest in the EU. The consequence of this decrease of the unemployment rate is a dramatic increase of the share of fixed-term workers and the precariousness in wages and working conditions. On the contrary, Germany has reported relatively stable rate of unemployment moving from $8.2 \%$ in 1995 to $7.9 \%$ in 2000 (see table 1). Another dominant feature of the Spanish labour market is the high level of wage inequality. During the 1990s Spain reported similar levels of inequality to the US, which has been considered in the last decades as the paradigm of the unequal labour market, whereas Germany has reported one of the lowest levels of inequality among developed economies ${ }^{3}$.

The marked differences in the tenure structures of the housing stock, in the housing market policies, in the labour market performance and in the accessibility to the credit market between Spain and Germany mean that uncertainty in labour income and attitudes towards risk might differ substantially between both countries.

\section{Theoretical framework: a simple formula}

The decision of homeownership is usually modeled as a function of household income, the costs of owning compared to costs of renting, and a set of demographic variables (age, household size, etc.). In this section we develop a simple formula that accounts for the effects of labour income uncertainty in the housing tenure choice. We specify a household utility function that depends on owning and renting costs and labour income. Labour income is assumed to be additively decomposable between a deterministic and stochastic component. For the sake of

\footnotetext{
${ }^{3}$ In a cross-country comparison using the Gini index, Bradbury (1993) reported a level of wage inequality of 0.3 for the US and of 0.2 for Germany during the late 1980s and early 1990s. Diaz-Serrano (2001) estimated for the same period a Gini value around 0.29 for Spain.
} 
simplicity, we assume no uncertainty in the rental market ${ }^{4}$, and that owning and renting are mutually exclusive options. This latter assumption is not trivial, since for the most of the households is not economically affordable paying a mortgage and a rent simultaneously. A household will decide to buy rather than to rent if the expected utility of owning during the tenure period $T$ is greater than that the expected utility of renting

$$
E \int_{0}^{T} U\left(\tilde{P}_{O}, w_{i t}\right) e^{-\rho t} d t \geq E \int_{0}^{T} U\left(\tilde{P}_{R}, w_{i t}\right) e^{-\rho t} d t
$$

where $U(\cdot)$ is the indirect utility associated with owning or renting. $\tilde{P}_{O}$ is the real cost of owning, $\tilde{P}_{R}$ is the real cost of renting, the term $\rho$ is the household's subjective rate of time preference, and $w_{i}$ is the labour income for household $i$, which is assumed to be

$$
w_{i t}=y_{i}+\varepsilon_{i t} .
$$

In expression (2), $y_{i}$ is "permanent income" and $\varepsilon_{i t}$ is a random term picking up shocks in income due to market forces. We assume that $E\left(\varepsilon_{i t}\right)=0, E\left(\varepsilon_{i t}\right)^{2}=\sigma_{\varepsilon}^{2}, E\left(\varepsilon_{i t}\right)^{3}=\kappa_{\varepsilon}^{3}$, and $E\left(w_{i t}\right)=y_{i}$. Future changes in the permanent income are perfectly foreseeable by individuals, whereas future changes in the random shocks due to $\varepsilon_{i t}$ are totally unknown. We label this random term, $\varepsilon_{i t}$, transitory shock in labour income. Our assumptions about the signs of the partial derivatives of $U(\bullet)$ are: $U_{P}^{\prime}<0, U_{P}^{\prime \prime}<0, U_{P}^{\prime \prime \prime}=0, U_{y}^{\prime}>0, U_{y}^{\prime \prime}<0$, and $U_{y}^{\prime \prime \prime}>0$. This latter assumption guarantees decreasing risk-aversion. As it is pointed out in Tsiang (1974), increasing absolute risk aversion is absurd. Therefore, we should expect that a risk-averse individual displays

\footnotetext{
${ }^{4}$ The consideration of such a class of uncertainty would not alter our key result.
} 
preference for skewness in addition to aversion to dispersion (risk) of the probability distribution of returns (earnings), so that, we should expect that $U_{y}^{\prime \prime \prime}>0$.

Define $E\left(\tilde{P}_{O}\right)=\bar{P}_{O}$ and $E\left(\tilde{P}_{R}\right)=\bar{P}_{R}$. Applying multivariate Taylor series expansion up to the third order around $\bar{P}_{O}$ and $y$ on the left-hand-side in (1) yields

$$
\begin{aligned}
& U\left(\bar{P}_{O}, y\right) \int_{0}^{T} e^{-\rho t} d t+ \\
& +\frac{1}{2}\left[U_{P}^{\prime \prime}\left(\bar{P}_{O}, y\right) \int_{0}^{T} E\left(\tilde{P}_{O}-\bar{P}_{O}\right)^{2} e^{-\rho t} d t+U_{y}^{\prime \prime}\left(\bar{P}_{O}, y\right) \int_{0}^{T} E\left(\varepsilon_{t}^{2}\right) e^{-\rho t} d t\right]+ \\
& \quad+\frac{1}{6}\left[U_{P}^{\prime \prime \prime}\left(\bar{P}_{O}, y\right) \int_{0}^{T} E\left(\tilde{P}_{O}-\bar{P}_{O}\right)^{3} e^{-\rho t} d t+U_{y}^{\prime \prime \prime}\left(\bar{P}_{O}, y\right) \int_{0}^{T} E\left(\varepsilon_{t}^{3}\right) e^{-\rho t} d t\right]= \\
& =\left[U\left(\bar{P}_{O}, y\right)+\frac{1}{2} U_{P}^{\prime \prime}\left(\bar{P}_{O}, w_{t}\right) \sigma_{P}^{2}+\frac{1}{2} U_{y}^{\prime \prime}\left(\tilde{P}_{O}, y\right) \sigma_{\varepsilon}^{2}+\right. \\
& \left.\quad+\frac{1}{6} U_{y}^{\prime \prime \prime}\left(\tilde{P}_{O}, y\right) \kappa_{P}^{3}+\frac{1}{6} U_{y}^{\prime \prime \prime}\left(\tilde{P}_{O}, y\right) \kappa_{\varepsilon}^{3}\right] \frac{1}{\rho}\left(1-e^{-\rho t}\right)
\end{aligned}
$$

where $\sigma_{P}^{2}=E\left(\tilde{P}_{O}-\bar{P}_{O}\right)^{2}$ and $\kappa_{P}^{3}=E\left(\tilde{P}_{O}-\bar{P}_{O}\right)^{3}$ represent uncertainty (variance) and asymmetry (skewness) of owner-occupation costs, respectively.

Applying multivariate first-order Taylor series expansion around $y$ and the point where the real cost of renting equalizes the expected price of owning $\left(\tilde{P}_{R}=\bar{P}_{O}\right)$ on the right-hand-side of (1) we get

$$
\begin{aligned}
& U\left(\bar{P}_{O}, y\right) \int_{0}^{T} e^{-\rho t} d t+\left[U_{P}^{\prime}\left(\bar{P}_{O}, y\right) \int_{0}^{T} E\left(\tilde{P}_{R}-\bar{P}_{O}\right) e^{-\rho t} d t+U^{\prime}\left(\bar{P}_{O}, y\right) \int_{0}^{T} E\left(\varepsilon_{t}\right) e^{-\rho t} d t\right]= \\
& =\left[U\left(\bar{P}_{O}, y\right)+U_{P}^{\prime}\left(\bar{P}_{O}, y\right) E\left(\tilde{P}_{R}-\bar{P}_{O}\right)+U_{y}^{\prime}\left(\bar{P}_{O}, y\right) E\left(\varepsilon_{t}\right)\right] \frac{1}{\rho}\left(1-e^{-\rho t}\right)
\end{aligned}
$$

where $U_{P}^{\prime}=\partial U / \partial P_{O}$ and $U_{y}^{\prime}=\partial U / \partial y$. Replacing (3) and (4) in (1) and rearranging yields 


$$
\frac{1}{2} \alpha\left(\frac{1}{3} \beta\left[\kappa_{\varepsilon}^{3}+\lambda_{3} \kappa_{P}^{3}\right]-\lambda_{2} \sigma_{P}^{2}-\sigma_{\varepsilon}^{2}\right)-\lambda_{1}\left(\tilde{P}_{R}-\bar{P}_{O}\right) \geq 0
$$

where $\lambda_{1}=U_{P}^{\prime} / U_{y}^{\prime}$ is marginal rate of substitution, $\lambda_{2}=U_{P}^{\prime \prime} / U_{y}^{\prime \prime}$, and $\lambda_{3}=U_{P}^{\prime \prime \prime} / U_{y}^{\prime \prime \prime}$. The term $\alpha=U_{y}^{\prime \prime} /-U_{y}^{\prime}$ is the household's absolute risk aversion (see Pratt, 1964), and $\beta=U_{y}^{\prime \prime \prime} /-U_{y}^{\prime \prime}$, by analogy to $\alpha$, is the "skewness affection" (see Hartog and Vijverberg 2002, and Diaz-Serrano et al. 2003). According to the previous assumptions on the signs of the first, second and third derivatives of $U(\bullet)$, we get that $\lambda_{1}<0, \lambda_{2}>0$ and $\lambda_{3}=0$. The latter reduces expression (5) to

$$
\frac{1}{2} \alpha\left(\frac{1}{3} \beta \kappa_{\varepsilon}^{3}-\lambda_{2} \sigma_{P}^{2}-\sigma_{\varepsilon}^{2}\right)-\lambda_{1}\left(\tilde{P}_{R}-\bar{P}_{O}\right) \geq 0
$$

Expression (6) highlights the pivotal role of risk attitudes $(\alpha)$ in the housing tenure decision. The decision of owner-occupation crucially depends on the degree of risk aversion $\alpha$, and the difference between expected renting and owning prices $\left(\bar{P}_{R}-\bar{P}_{O}\right)$. When households are risk neutral $(\alpha=0)$, the decision is just limited to real renting costs and household appreciation on expected owning costs. However, if households are risk averse $(\alpha>0)$, the decision will also depend on the terms in firsts-parenthesis on the left-hand-side of equation (6). With $(\alpha>0)$, labour income uncertainty $\left(\sigma_{\varepsilon}^{2}\right)$ and uncertainty in owner-occupation costs $\left(\sigma_{P}^{2}\right)$ exert a negative effect on the decision to own. In addition, if households exhibit "skewness affection" $(\beta>0)$, labour income skewness $\left(\kappa_{\varepsilon}^{3}\right)$ raises the probability of homeownership. However, if the gap between renting and owning costs is positive and high enough this renting cost effect could remove the risk-aversion effect. 


\section{Empirical framework}

\subsection{Econometric model}

The difference in the households indirect utility between owning and renting expressed in (6) can be represented by a latent (unobservable) index

$$
y_{i}^{*}=f\left(y_{p i}, y_{\varepsilon i}, \sigma_{\varepsilon i}^{2}, \kappa_{\varepsilon i}^{3}, c_{i}, L_{i}, H_{i}\right)
$$

where $f(\bullet)$ is function of the observable variables

- $\quad y_{p i}:$ Permanent labour income

- $\quad y_{\varepsilon i}$ : Transitory labour income

- $\sigma_{\varepsilon i}^{2}$ : Labour income uncertainty

- $\quad \kappa_{\varepsilon i}^{2}:$ Labour income skewness

- $\quad c_{i}$ : Owner-occupation and renting cost

- $\quad L_{i}$ : Employment and unemployment trajectory of the head of household

- $\quad H_{i}$ : Household demographic characteristics

We cannot observe the utility of homeownership or renting, only whether the dwelling is purchased or not. Therefore, what we observe is

$$
\begin{aligned}
& y=1 \quad \text { if } \quad y^{*}>0, \\
& y=0 \quad \text { if } \quad y^{*} \leq 0
\end{aligned}
$$

where $P\left(y_{i}^{*}>0 \mid y_{p i}, y_{\varepsilon i}, \sigma_{\varepsilon i}^{2}, \kappa_{\varepsilon i}^{3}, c_{i}, L_{i}, H_{i}\right)$ will be estimated by the standard binary choice probit model. 


\subsection{Measuring income uncertainty}

Income uncertainty is usually measured by the coefficient of variation (hereafter CV) of income. However, although this measure may be a plausible proxy for income risk, it does not capture the true individuals' degree of (un)certainty about their future labour income. We believe that individuals have some foresight about their future labour income, whereas the $\mathrm{CV}$ assumes that individuals have no prospect about it. We find this latter assumption not very realistic. Individuals know that their wage depends, among others, on their personal characteristics, skills and experience, and they also know the expected value of these characteristics in the labour market ${ }^{5}$. Thus, we assume that the individual's unforeseeable income is only a share of the overall labour income, and it arises from unanticipated shocks due to market forces (unemployment, job mobility, business cycle, etc.).

One clear example of such a source of uncertainty would be workers paid in base to piece rate system. Another example would be a salesperson that receives a fix wage plus a commission based on his/her turnover. In these two cases workers' earnings are highly sensitive to production or demand shocks. To some extent, the amount of labour earnings received from this type of payment systems not only depend on market forces, but also on individual innate abilities, which constitutes a permanent source of shocks in earnings. The methodology proposed in this paper to compute transitory income permits to separate these individual-specific permanent shocks from the transitory ones derived from market forces. Job mobility is also assumed to produce shocks in labour income. When a worker is fired because of a negative shock in demand, he/she cannot ensure that the wage rate in the next job is going to be as high as in his/her previous job. The difference in the wage level between the previous and the current job would represent a shock in

\footnotetext{
${ }^{5}$ We refer to the literature on reservation wages for a deeper insight on this assumption.
} 
income. However, individuals will try to ensure that the wage in the new job is at least equal to their reservation wage. This reservation wage is determined, among others, by individual's personal characteristics (education, experience, etc.), and its value in the labour market is perfectly known.

Following equation (2) and the assumptions on the degree of knowledge that individuals have on their future permanent income, we model individual's labour income as

$$
\ln \left(w_{i t}\right)=X_{i t} \beta+u_{i}+\varepsilon_{i t},
$$

where the subscripts $i$ and $t$ indexes households and time, respectively; $\ln \left(w_{i t}\right)$ is the natural logarithm of the individual's yearly labour income; $X_{i t}$ is a set of explanatory variables referring to the household head; $u_{i}$ is an intrinsic individual time-constant shock in earnings ${ }^{6} ; \varepsilon_{i t}$ is a timevarying random shock in earnings; and $\beta$ is the set of parameters to be estimated. We estimate equation (8) using a panel data model with random effects (see Hsiao, 1986, Ch. 4).

In equation (8), the term $y_{i t}=X_{i t} \beta+u_{i}$ represents the permanent income ${ }^{7}$ and it is assumed be known ex-ante by individuals, whereas the term $\varepsilon_{i t}$ is associated with transitory labour income, and it is only known after their realization.

According with the assumptions mentioned above, the labour income variables used in the choice equation (7) are defined as follows:

- Individual's permanent labour income: $\bar{y}_{p i}=\frac{1}{7} \sum_{t=1994}^{2000} \exp \left(X_{i t} \hat{\beta}+\hat{u}_{i}\right)$

\footnotetext{
${ }^{6}$ This term picks up the individual heterogeneity and it represents a permanent shock in labor income. The panel data model (8) allows to purge this specific-individual effect from the transitory shocks $\varepsilon_{i t}$ caused by market forces.

${ }^{7}$ The explanatory variables in $X_{i t}$ are assumed to generate systematic labor income differentials. Individuals know the unit price of these variables in the labor market, and hence they can foresee future changes in their permanent income
} 
- Individual's transitory labour income: $\bar{y}_{\varepsilon i}=\frac{1}{7} \sum_{t=1994}^{2000} \exp \left(\hat{\varepsilon}_{i t}\right)$

- Individual's labour income uncertainty: $\hat{\sigma}_{\varepsilon i}^{2}=\frac{1}{7} \sum_{t=1994}^{2000}\left\{\exp \left(\hat{\varepsilon}_{i t}\right)-\bar{y}_{\varepsilon i}\right\}^{2}$

- Individual's labour income skewness: $\hat{\kappa}_{\varepsilon i}^{3}=\frac{1}{7} \sum_{t=1994}^{2000}\left\{\exp \left(\hat{\varepsilon}_{i t}\right)-\bar{y}_{s i}\right\}^{3}$,

where the exponential transformation is applied in order to transfer back to money metric the different components of the $\ln \left(w_{i t}\right)$.

\section{Data and variable construction}

\subsection{The dataset}

The data comes from the European Community Household Panel (ECHP). In this paper we use the waves covering the period 1994-2000 for Germany and Spain. For the first three waves (1994-1996), the ECHP files for Germany contain information coming from both the German Socio Economic Panel (GSOEP) and the ECHP, whereas for the period (1997-2000) the whole sample comes from the GSOEP. For Spain, all the sample period (1994-2000) comes from the original ECHP. The number of surveyed households for Germany ranges from 11,175 in 1994 to 5,693 in 2000, and from 7,206 in 1994 to 5,132 in 2000 for Spain. Table 2 displays the different sample sizes for each wave. The ECHP and the GSOEP contain information not only at household, but also at individual level. The household characteristics that we consider relevant for the present study are the household size and composition, demographic characteristics, income and accommodation. The accommodation questions provide information about the type of dwelling, the year when the household moved there, renting costs and mortgage payments. 
Besides household information, we also use personal information (age, gender, etc.) and socioeconomic characteristics (employment status, earnings, education, etc.).

Insert table 2 here

\subsection{Sample restrictions}

In order to estimate labour income uncertainty, we restrict our sample to the household heads. There are two reasons to impose this restriction. Firstly, as we are interested in income uncertainty arising from labour market forces, to calculate income risk we need to keep out other sources of household income that tend to display a very transitory nature and that have nothing to do with market forces. Secondly, household heads' labour income is the most important source of income for most of the households. Thus, the role it plays in the owner-occupation decision is more important than that played by other sources of household income. In table 3 we report the share of household head labour income in the overall household income for Germany and Spain.

Insert table 3 here

Our endogenous variable in the tenure choice equation (7) is a dummy variable that takes 1 if the household is owner-occupier and 0 if the household is a renter. In order to avoid possible bias in the estimated effects of the income variables on the probability of homeownership, we impose two further restrictions. Firstly, we keep out of the sample the households that have purchased the dwelling before the initial survey year, 1994. And second, we do not include the households that are recent owners but do not outstand a mortgage. The aim of these two restrictions is twofold. On one hand, we do not know the households' characteristics when de 
tenure decision is made for those who bought their dwelling before 1994. Hence, restricting transitions from renting to owning during the sample period allows matching the observed household characteristics with the tenure status decision. On the other hand, the tenure status of recent owners without a mortgage outstanding has probably nothing to do with the fundamentals and the influential variables assumed to affect the homeownership decision. They may well have inherited the dwelling or have received a free allowance out-of-pocket. Although this is a small fraction of our sample, keeping these households in the sample could obscure the relationship between the income variables and the probability of homeownership.

\subsection{Variables}

The matrix $X_{i}$ used to estimate household head's labour income equation (8) contains the following set of variables; gender, education, labour experience and its squared, tenure and its squared, weekly working hours and the type of labour contract. To estimate renting and owning costs used in the housing tenure choice equation (7) we use the real average monthly rent and the real monthly mortgage payments ${ }^{8}$ computed for each region (NUTS) $^{9}$. Permanent income $\left(y_{p i}\right)$, transitory income $\left(y_{\varepsilon I}\right)$, income uncertainty $\left(\sigma_{\varepsilon i}{ }^{2}\right)$, and income skewness $\left(\kappa_{\varepsilon}^{3}\right)$ are estimated as defined in expressions (9) to (12). The remaining variables in the choice equation (7) are defined in table 4. Among them, we account for household head's unemployment history, household size, household's capital income, and some household head's demographic characteristics such age

\footnotetext{
${ }^{8}$ The literature provides alternative ways to compute the owner costs based on subjective appreciation involving mortgage rates, property tax, loan-to-value ratios or house price inflation among others (see e.g. Rosen, 1979; Henderson and Ioannides, 1987; Haurin et al., 1994). Because our data lack most of these variables, we proxy the owning costs by the monthly mortgage payments.

9 The NUTS (nomenclature of territorial units for statistics) classification for Germany is Bader-Wuntterberg, Bayern, Berlin, Brandenburg, Bremen, Hamburg, Hessen, Mecklenburg-Vorpommem, Niedersachsen, NordrheinWestfalen, Rheinland-Pfalz, Saarlan, Sachsen, Sachsen-Anhalt, Schleswig-Holstein, and Thuringen. The Spanish NUTS are North-West (Galicia, Cantabria, Asturias), North-East (Pais Vasco, Navarra, Aragon), Center (CastillaLeon, Castilla-La Mancha, Extremadura), East (Catalunya, Valencia, Baleares), South (Andalucia, Murcia), Canarias and Madrid.
} 
and current marital status. In our choice equation we also control for the type of dwelling purchased, and the reason for changing the dwelling if any.

Insert table 4 here

\section{Estimation results}

In table 5 we report the sample means for the explanatory variables used in the earnings equation (8) and in the tenure choice equation (7). The sample statistics reveals that household head's characteristics determining permanent labour income (schooling, experience, tenure, weekly hours worked, and the type of contract) are systematically greater for owners than for renters. Therefore, it seams plausible to expect that household head's labour income profiles will display different patterns between both tenures status. To test this assumption, we estimate the earnings equation (8) separately for owners and renters. Results are reported in table 6. All coefficients are significant at $1 \%$ level and with the expected signs. We also carry out a Chow test of structural change between both tenures. With F-statistic of 127 for Germany we strongly reject the null hypothesis that owners and renters income profiles are equal. In the case of Spain, the F-statistic is only 2.52 , but high enough to reject the null hypothesis at $5 \%$ significance level. Hence, for both Spain and Germany, we estimate separated measures of permanent and transitory income, income uncertainty and skewness for owners and renters.

Insert table 5 here

Insert table 6 here 
Table 7 and 8 contain a descriptive analysis of the intertemporal income uncertainty and skewness measures. We include both types of measures, the ones calculated from labour income equation (8) and also from the standard formula of the CV and skewness (hereafter $\mathrm{K}$ ) over yearly labour income ${ }^{10}$. The summary statistics reveal that $\hat{\sigma}_{\varepsilon i}^{2}, \hat{\kappa}_{\varepsilon i}^{3}$ posses enough variability to look for effects in the choice equation (7). As expected, income uncertainty is markedly higher in Spain than in Germany. Time income distributions also tend to be substantially more positively skewed in Spain. This result is indicative of the fact that the labour market performance in both countries is very different.

We also find marked intra-country differences between tenures, i.e. systematic lesser income uncertainty and greater positive skewness for owners than for renters. In Germany, income uncertainty is about $35 \%$ greater for renters than for owners, whereas for Spain it is about $14 \%$ greater. Differences in income skewness between tenures are even more important, in Spain estimated skewness is six times greater for owners than for renters. The same proportion in absolute value is just 2.5 in Germany. Comparisons across population groups also behave according to expectations. As we predict in our theoretical formula (6), these results suggest that income uncertainty and skewness play a substantial role in the house tenure choices in both countries.

Insert table 7 here

Insert table 8 here

\footnotetext{
${ }^{10}$ The standard formula of the coefficient of variation is $\mathrm{CV}=\sigma_{\mathrm{y}} / \mu_{\mathrm{y}}$, and for skewness $\mathrm{K}=\Sigma\left(\mathrm{y}-\mu_{\mathrm{y}}\right)^{3} / \mathrm{T} \sigma_{\mathrm{y}}{ }^{3}$, where $\mu_{\mathrm{y}}$ is the time average of yearly income, and $\sigma_{\mathrm{y}}$ is the standard deviation.
} 
In the second step, intertemporal measures of income uncertainty and skewness are used to estimate the effect of earnings uncertainty and skewness on the discrete choice between renting and owning, we use a pooled cross-section probit ${ }^{11}$. Since our data set is a panel, in order to get unbiased estimates we select just the last wave the household has participated, and the tenure status is determined in that wave.

Results of the probit estimation of the choice equation (7) are reported in table 9. We focus on the results in columns (1) and (2) picking up the effects of the income variables based on the residuals of the income equation (8). In both countries we find a strong negative relationship between labour income uncertainty and the probability of homeownership. As we predict in our theoretical formula, the relationship with earnings skewness is also strongly significant and positive. In table 9 we also distinguish between negative and positive shocks. The variable called TI2 is a dummy variable that takes 1 if during the sample period (1994-2000) the absolute value of the average of the negative shocks is greater than the average of the positive ones. This variable exerts a significant negative effect on the probability of homeownership in both countries, whereas the effect of transitory income is positive. The average marginal effects reported in table 9 reveal that variables related to transitory income (average transitory income, uncertainty and skewness) have a markedly stronger effect in Spain than in Germany, whereas this is reversed for the effect of permanent income. As a control we also report the estimates using the $\mathrm{CV}$ as uncertainty measure and $\mathrm{K}$ as skewness, both variables are significant and with the expected signs.

The remainder variables in the choice equations also behave according to expectations. Employment variables are very important for the tenure status in both countries. Job mobility,

\footnotetext{
${ }^{11}$ The long run nature of housing purchases means that during our sample period households do not experience more than one transition from renting to owning. Therefore we discard the use of panel data estimation, since the potential improvements provided by this technique do not apply to our case.
} 
previous unemployment status and long run unemployment (12 or more months) tend to reduce significantly the probability of homeownership. The effect of these variables is, once more, stronger in Spain than in Germany. Public employees are more like to own in Germany, but do not in Spain. Households possessing greater capital income, and those where the household head's spouse is a wage earner also display a greater propensity to own. User costs are very significant and with the expected signs. Consistent with our theoretical formula, the greater the owner-occupancy cost, the lower the probability of homeownership. The opposite holds for the renting costs. However, this effect is more important across the German regions than in the Spanish ones. Concerning the type of dwelling, homeowners show a strong preference for detached and semi-detached houses.

\section{Conclusions and discussion}

In this paper, we expand the usual income uncertainty analysis (mean-variance) of the housing tenure decisions by deriving the effect of the asymmetry (skewness) in the income distribution on the probability of homeownership. We use a simple theoretical formula that allows determine the crucial role that both variance and skewness in income play on the housing tenure choices. In order to test empirically our theoretical results we perform reduced form equations estimates of the probability of homeownership in Germany and Spain. Our empirical results confirm the predictions derived from the theoretical formula, significant negative effect for risk and positive for skewness. This evidence suggests that households are risk averse and also exhibit "skewness affection" when they plan their home tenure status. Moreover, our results concerning income risk are consistent with previous empirical evidence from the US.

The alternative measures of income risk and skewness based on the estimated residuals of

earnings panel data equations have also shown a good performance. This confirms our 
assumptions about the degree of knowledge that individuals have about their future earnings. We also find that unemployment history of the household head exerts a significant effect on the probability of homeownership. Household heads that have been unemployed at least once after 1989 are less likely to own. This effect is augmented if they have experienced long duration unemployment (above 12 months).

The fact that our empirical estimations hold in both countries endows our theoretical and empirical results with a good consistency. It is remarkable that even in a so flexible credit market as the Spanish, income uncertainty is still a barrier to homeownership. This circumstance has significant implications for both public and private institutions. Recently there exist the perception that the state pension fund system will experience severe restrictions in the long-run in Germany and Spain. To be more specific, the forecast about future demographic evolution and on future social security contributions, predict a crash of the Spanish pension system about the year 2020. Undoubtedly, homeownership is one of the best hedging tools against such a pessimistic scenario. In this context, we claim that more active public housing welfare policies, like for instance the provision of public mortgage downpayment assistance, are necessary in order to promote homeownership among households facing higher rates of income uncertainty.

In 1999 the German government approved a new insolvency law that relaxed the borrower's degree of liability by allowing himself to declare in "private bankruptcy". This situation permits to an overly indebted borrower solve the outstanding financial obligations by a court settlement in case it is not possible do it out of the court. It represents a first step for relaxing the extremely conservative German credit market that can encourage to German borrowers to assume higher levels indebtedness. Undoubtedly, it is a small door open in order to promote accessibility to mortgage loans for those with more volatile income, but maybe not 
enough to reach a more desirable levels of homeownership that allow most of the households to face up to the expected future restrictions in the German pension system.

The corollary of our results also applies to the existing private mortgage payment insurance policies offered by credit institutions. Pryce and Keoghan (2002) find empirical evidence for the UK that mortgage borrowers most at risk are less likely to undertake such private mortgage insurance products. According to this, it could be that credit institutions need to redesign their mortgage protection instruments in order to make it more affordable and cover a wider range of households' financial risks.

The understanding to what extent the (in)accessibility to a mortgage loan is driven by credit constraints or by households' aversion to the risk of a mortgage downpayment is still a relevant question to be answered. This exercise would require suitable data on households' credit quality constraints (see e.g. Rosenthal 2002, or Barakova et al. 2003). It is plausible to expect a positive relationship between constraints in the accessibility to mortgage loans and households' income uncertainty in a conservative credit market like the German one, however, but not necessarily in a flexible credit market like the Spanish one. Although we find this could be a very interesting extension of this work, it surpasses the goals of this paper. Hence, further research on this issue is encouraged. 


\section{References}

Barakova, I.; R.W. Bostic; P.S. Calem and S.M. Wachter (2003), Does credit quality matter for homeownership?, Journal of Housing Economics 12, pp. 318-336.

Bradbury, B. (1993): Male pre and tax wage inequality: a six country comparison, The Luxembourg Income Study working paper 90. Luxembourg: CEPS INSTEAD.

Chung, E.C. and D.R. Hauring (2002), Housing choices and uncertainty: the impact of stochastic events, Journal of Urban Economics 52, 193-216.

CIRIEC (2003), Housing statistics in the EU 2002, International Centre for Research and Information on the Public and Cooperative Economy, University of Liege, Belgium.

DeSalvo, J.S. and L.R. Eeckhoudt (1982), The Effect of Unemployment Risk on Consumption Behavior, Zeitschrift fur Nationalokonomie 42, 411-418.

Diaz-Serrano, L.; J. Hartog and H.S. Nielsen (2003), Compensating wage differentials for schooling risk in Denmark, IZA discussion papers \#963, Bonn, Germany.

Fu, Y. (1995), Uncertainty, liquidity, and housing choices, Regional Science and Urban Economics 25, 223-236.

Green, G.; J. Coder and P. Ryscavage (1992), International Comparisons of Earnings Inequality for Men in the 1980s, Review of Income and Wealth 38, pp. 1-15.

Hartog, J. and W. Vijverberg (2002), Do wages really compensate for risk aversion and skewness affection, IZA discussion papers \#426, Bonn, Germany.

Hartog; J.; E.J.S. Plug, L. Diaz-Serrano and A.J.C. Vieira, (2003), Risk compensation in wages: a replication, Empirical Economics 28, pp. 639-647.

Haurin, D.R. and H.L. Gill (1987), Effects of income variability on the demand for owneroccupied housing, Journal of Urban Economics 22, 136-150. 
Haurin, D.R. (1991), Income variability, homeownership, and housing demand, Journal of Housing Economics, 60-74.

Haurin, D.R.; P.H. Hendershott and D. Kim (1994), Housing decisions of American youth, Journal of Urban Economics 35, pp. 28-45.

Henderson, J.V. and Y. Ioannides (1983), A model of housing tenure choice, American Economic Review 73, 98-113.

Henderson, J.V. and Y. Ioannides (1987), Owner occupancy: consumption vs. investment demand, Journal of Urban Economics 21, 228-241.

Hsiao, C. (1986), Analysis of Panel Data, Cambridge University Press, Cambridge.

Ioannides, Y.M. (1979), Temporal risks and the tenure decision in housing markets, Economic Letters 4, pp. 293-297.

Kahneman D. and A. Tversky (1979), Prospect theory: an analysis of decision under risk, Econometrica 47, 263-291.

Kahneman D. and A. Tversky (1991), Loss aversion in riskless choice: a reference-dependent model, Quarterly Journal of Economics 106, 1039-1061.

King, A. (1974), Occupational choice, risk aversion, and wealth, Industrial Labour Relations Review, July, 586-596.

McGoldrick, K. (1995), Do women receive compensating wages for earnings uncertainty?, Southern Economic Journal, 62, 210-222.

Neuteboom, P. (2003), A European comparison of the costs and risks of mortgages for owneroccupiers, European Journal of Housing Policy 3, pp. 155-171.

Pratt, W. (1964): "Risk Aversion in the Small and in the Large", Econometrica 32, pp. 122-136.

Pryce G. and M. Keoghan (2002), Unemployment insurance for mortgage borrowers: is it viable and does it cover those most in need?, European Journal of Housing Policy 2, pp. 87-171. 
Robst, J.; R. Deitz and K. McGoldrick (1999), Income variability, uncertainty and housing tenure choice, Regional Science and Urban Economics 29, 219-229.

Rosen, H.S. (1979), Housing decision and the US income tax: and econometric analysis, Journal of Public Economics 11, 1-24.

Rosen, H.T.; K.T. Rosen and D. Holtz-Eakin (1984), Housing tenure, uncertainty and taxation, Review of Economics and Statistics 46, 405-416.

Rosenthal, S.S. (2002), Eliminating credit barriers: how far can we go? In: Retsinas, N.P., Belsky, E.S. (Eds.), Low-Income Homeownership, pp. 111-145.

Tsiang, S.C. (1974): "The rationale of the mean-standard deviation analysis, skewness preference, and the demand for money", American Economic Review 64, 354-371.

Turnbull, G.K.; J.L. Glascock and C.F. Sirmans (1991), Uncertain income and housing price and location choice, Journal of Regional Science 31, 417-433. 
Table 1: Selected housing indicators in the EU countries

\begin{tabular}{lrr|rr|rrr|rr}
\hline \hline & $\begin{array}{c}\text { Unemployment } \\
\text { rate }\end{array}$ & \multicolumn{2}{|c|}{$\begin{array}{c}\text { Change in some } \\
\text { Rented dwelling }\end{array}$} & \multicolumn{2}{c}{ housing costs index } & Vacant dwellings \\
\hline Belgium & 1995 & 2000 & 1995 & 1999 & $(1)$ & $(2)$ & $(3)$ & $1991-96$ & $1998-01$ \\
\hline Denmark & $10 \%$ & $7 \%$ & na & $23 \%$ & $4 \%$ & $2 \%$ & $48 \%$ & na & na \\
Germany & $7 \%$ & $5 \%$ & $44 \%$ & $45 \%$ & $11 \%$ & $4 \%$ & $51 \%$ & $5 \%$ & $4 \%$ \\
Greece & $8 \%$ & $8 \%$ & $58 \%$ & $57 \%$ & $7 \%$ & na & $28 \%$ & $3 \%$ & $8 \%$ \\
Spain & $9 \%$ & $11 \%$ & na & $21 \%$ & $26 \%$ & $-2 \%$ & $189 \%$ & $32 \%$ & $34 \%$ \\
France & $23 \%$ & $14 \%$ & $14 \%$ & $11 \%$ & $20 \%$ & $23 \%$ & $142 \%$ & $15 \%$ & $20 \%$ \\
Ireland & $12 \%$ & $10 \%$ & $40 \%$ & $38 \%$ & $5 \%$ & $-1 \%$ & $26 \%$ & $8 \%$ & $7 \%$ \\
Italy & $12 \%$ & $4 \%$ & $18 \%$ & $18 \%$ & na & na & $170 \%$ & $10 \%$ & na \\
Luxembourg & $12 \%$ & $11 \%$ & na & na & $6 \%$ & na & $79 \%$ & $21 \%$ & $20 \%$ \\
Nederland & $3 \%$ & $2 \%$ & $26 \%$ & na & na & na & na & $4 \%$ & na \\
Austria & $7 \%$ & $3 \%$ & $52 \%$ & $48 \%$ & $11 \%$ & $4 \%$ & $84 \%$ & $2 \%$ & $2 \%$ \\
Portugal & $4 \%$ & $4 \%$ & $42 \%$ & $41 \%$ & $9 \%$ & $5 \%$ & na & na & na \\
Finland & $7 \%$ & $4 \%$ & na & $28 \%$ & $11 \%$ & na & $236 \%$ & $11 \%$ & na \\
Sweden & $15 \%$ & $10 \%$ & $30 \%$ & $31 \%$ & $17 \%$ & na & na & $7 \%$ & $9 \%$ \\
UK & $9 \%$ & $6 \%$ & na & na & $8 \%$ & $39 \%$ & $6 \%$ & $3 \%$ & $3 \%$ \\
\hline \hline
\end{tabular}

Source: CIDIREC (2003).

Notes: (1) 1995-98 change in the price index for private rented dwellings; (2) 1995-2000 change in price index for newly completed dwelling; (3) 1995-2000 change in the index of outstanding mortgage loans. 
Table 2: Sample sizes by year and data source.

\begin{tabular}{|c|c|c|c|c|c|c|c|c|}
\hline & \multicolumn{4}{|c|}{ \# of households } & \multicolumn{4}{|c|}{ \# of individuals } \\
\hline & \multicolumn{3}{|c|}{ Germany } & \multirow{2}{*}{\begin{tabular}{|c|} 
Spain \\
Original \\
\end{tabular}} & \multicolumn{3}{|c|}{ Germany } & \multirow{2}{*}{\begin{tabular}{|c|} 
Spain \\
Original
\end{tabular}} \\
\hline & Original & & & & Priginal & & & \\
\hline & ЕСНР & GSOEP & Both & EСНP & ЕСНP & GSOEP & Both & ЕСНP \\
\hline 1994 & 4,968 & 6,207 & 11,175 & 7,206 & 9,490 & 12,233 & 21,723 & 17,893 \\
\hline 1995 & 4,688 & 6,336 & 11,024 & 6,522 & 9,002 & 12,542 & 21,544 & 16,263 \\
\hline 1996 & 4,593 & 6,259 & 10,852 & 6,267 & 8,746 & 12,295 & 21,041 & 15,640 \\
\hline 1997 & & 6,163 & 6,163 & 5,794 & & 12,059 & 12,059 & 14,819 \\
\hline 1998 & & 5,962 & 5,962 & 5,485 & & 11,562 & 11,562 & 13,779 \\
\hline 1999 & & 5,847 & 5,847 & 5,418 & & 11,288 & 11,288 & 13,104 \\
\hline 2000 & & 5,693 & 5,693 & 5,132 & & 10,987 & 10,987 & 12,317 \\
\hline \# observations & & & 56,716 & 41,824 & & & 110,204 & 103,815 \\
\hline
\end{tabular}


Table 3: Share of household head labour income overall household income.

\begin{tabular}{c|rr|rr}
\hline \hline & \multicolumn{2}{|c|}{ Spain } & \multicolumn{2}{c}{ Germany } \\
\hline & $\mathbf{1 9 9 5}$ & $\mathbf{2 0 0 0}$ & $\mathbf{1 9 9 5}$ & $\mathbf{2 0 0 0}$ \\
\hline Percentile & & & & \\
10 & $30.4 \%$ & $31.4 \%$ & $14.8 \%$ & $23.3 \%$ \\
25 & $50.3 \%$ & $48.2 \%$ & $31.9 \%$ & $33.1 \%$ \\
50 & $73.7 \%$ & $69.0 \%$ & $68.1 \%$ & $64.3 \%$ \\
75 & $99.6 \%$ & $98.4 \%$ & $95.0 \%$ & $86.2 \%$ \\
90 & $100.0 \%$ & $99.9 \%$ & $98.9 \%$ & $98.8 \%$ \\
\hline Average & $70.6 \%$ & $68.9 \%$ & $64.5 \%$ & $61.6 \%$ \\
\hline Sample size & 3,542 & 1,903 & 7,386 & 3,081 \\
\hline \hline
\end{tabular}

Source: Own computations based on the ECHP. 
Table 4: Definition of some variables in the housing tenure choice equation (6)

\begin{tabular}{|c|c|}
\hline Variable name & Definition \\
\hline Unemp89 & $\begin{array}{l}\text { Dummy variable takes } 1 \text { if the household head has been unemployed at } \\
\text { least once after } 1989 .\end{array}$ \\
\hline Longun89 & $\begin{array}{l}\text { Dummy variable takes } 1 \text { if the household head has been unemployed } \\
\text { during } 12 \text { or more consecutive months at least once after } 1989 .\end{array}$ \\
\hline Public & Dummy variable takes 1 if the household head is a public worker \\
\hline Hsize & Household size (number of household members) \\
\hline Married & Dummy variable takes 1 if the household head is married \\
\hline MaritalCh & $\begin{array}{l}\text { Dummy variable takes } 1 \text { if the household head has experienced a } \\
\text { marital status change after } 1994\end{array}$ \\
\hline Wspouse & $\begin{array}{l}\text { Dummy variable takes } 1 \text { if the household head's spouse is a wage } \\
\text { earner }\end{array}$ \\
\hline \multicolumn{2}{|l|}{ Age } \\
\hline & Age of the household head \\
\hline 1 ige & Age squared \\
\hline Jobmobil & $\begin{array}{l}\text { Dummy variable takes } 1 \text { if the dwelling purchased is a flat (the } \\
\text { alternative purchasing option would be a detached or semi-detached } \\
\text { house) }\end{array}$ \\
\hline Permobil & Dummy variable takes 1 if the change of dwelling is due to job motives \\
\hline & $\begin{array}{l}\text { Dummy variable takes } 1 \text { if the change of dwelling is due to personal } \\
\text { motives (the alternative mobility option to this and Jobmobil would be a } \\
\text { change due to dwelling motives). }\end{array}$ \\
\hline
\end{tabular}


Table 5: Sample means (1994-2000)

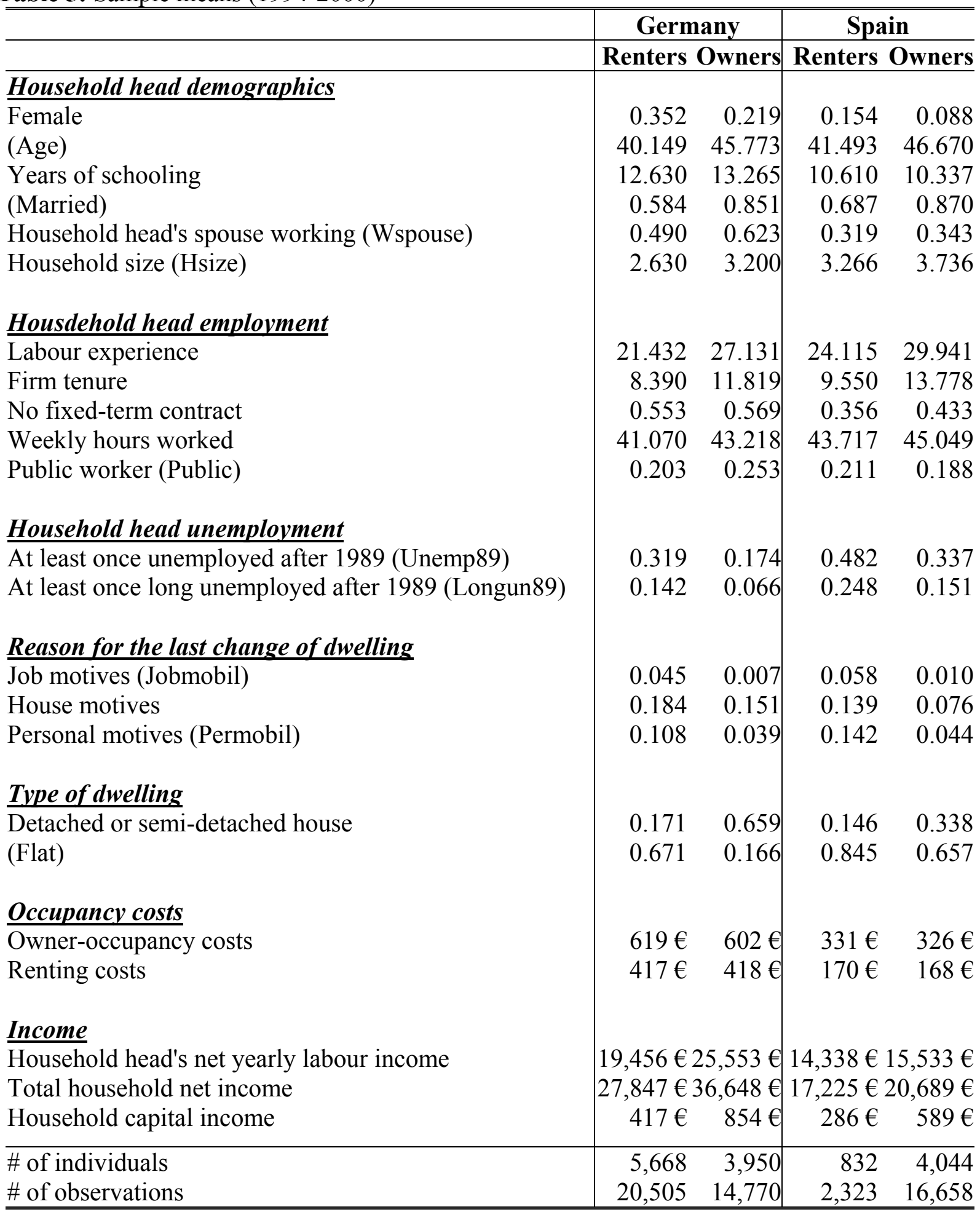

Source: Own computations based on the ECHP.

Notes: The names in parenthesis refer to the variables defined in table 4 . 
Table 6: Panel data random effects estimates of labour income equation (7)

\begin{tabular}{|c|c|c|c|c|c|c|}
\hline & \multicolumn{3}{|c|}{ Germany } & \multicolumn{3}{|c|}{ Spain } \\
\hline & Owners & Renters & $\begin{array}{c}\text { Pooled } \\
\text { sample }\end{array}$ & Owners & Renters & $\begin{array}{c}\text { Pooled } \\
\text { sample }\end{array}$ \\
\hline Constant & $\begin{array}{r}8.2875 \\
(68.91)\end{array}$ & $\begin{array}{c}7.7986 \\
(81.57)\end{array}$ & $\begin{array}{r}7.9459 \\
(107.04)\end{array}$ & $\begin{array}{r}12.9485 \\
(103.46)\end{array}$ & $\begin{array}{r}12.0887 \\
(41.04)\end{array}$ & $\begin{array}{r}12.8522 \\
(111.69)\end{array}$ \\
\hline Years of schooling & $\begin{array}{r}0.0399 \\
(11.92)\end{array}$ & $\begin{array}{r}0.0354 \\
(12.93)\end{array}$ & $\begin{array}{r}0.0375 \\
(17.29)\end{array}$ & $\begin{array}{c}0.0518 \\
(21.22)\end{array}$ & $\begin{array}{r}0.0618 \\
(10.18)\end{array}$ & $\begin{array}{c}0.0518 \\
(22.47)\end{array}$ \\
\hline Experience & $\begin{array}{r}0.0152 \\
(3.90)\end{array}$ & $\begin{array}{r}0.0236 \\
(9.23)\end{array}$ & $\begin{array}{c}0.0242 \\
(11.55)\end{array}$ & $\begin{array}{r}0.0253 \\
(6.68)\end{array}$ & $\begin{array}{r}0.0120 \\
(1.93)\end{array}$ & $\begin{array}{r}0.0241 \\
(7.10)\end{array}$ \\
\hline Experience squared & $\begin{array}{r}-0.0003 \\
(-4.95)\end{array}$ & $\begin{array}{r}-0.0005 \\
(-9.33)\end{array}$ & $\begin{array}{c}-0.0005 \\
(-11.78)\end{array}$ & $\begin{array}{r}-0.0004 \\
(-7.09)\end{array}$ & $\begin{array}{r}-0.0003 \\
(-1.95)\end{array}$ & $\begin{array}{r}-0.0004 \\
(-7.48)\end{array}$ \\
\hline Firm tenure & $\begin{array}{r}0.0456 \\
(12.00)\end{array}$ & $\begin{array}{r}0.0773 \\
(24.5)\end{array}$ & $\begin{array}{r}0.0635 \\
(26.21)\end{array}$ & $\begin{array}{r}0.0578 \\
(13.07)\end{array}$ & $\begin{array}{r}0.0831 \\
(7.59)\end{array}$ & $\begin{array}{c}0.0593 \\
(14.44)\end{array}$ \\
\hline Firm tenure squared & $\begin{array}{r}-0.0013 \\
(-7.75)\end{array}$ & $\begin{array}{l}-0.0025 \\
(-18.18)\end{array}$ & $\begin{array}{l}-0.0020 \\
(-18.53)\end{array}$ & $\begin{array}{r}-0.0018 \\
(-9.68)\end{array}$ & $\begin{array}{r}-0.0024 \\
(-5.09)\end{array}$ & $\begin{array}{l}-0.0018 \\
(-10.46)\end{array}$ \\
\hline $\log$ (weekly hours) & $\begin{array}{r}0.3774 \\
(14.05)\end{array}$ & $\begin{array}{r}0.4270 \\
(18.44)\end{array}$ & $\begin{array}{r}0.4039 \\
(23.05)\end{array}$ & $\begin{array}{r}0.0805 \\
(2.83)\end{array}$ & $\begin{array}{r}0.2905 \\
(4.04)\end{array}$ & $\begin{array}{r}0.1050 \\
(3.97)\end{array}$ \\
\hline No fixed-term contract & $\begin{array}{r}0.0483 \\
(5.44)\end{array}$ & $\begin{array}{r}0.0502 \\
(6.34)\end{array}$ & $\begin{array}{r}0.0465 \\
(7.90)\end{array}$ & $\begin{array}{c}0.1394 \\
(11.31)\end{array}$ & $\begin{array}{r}0.0912 \\
(2.65)\end{array}$ & $\begin{array}{c}0.1311 \\
(11.34)\end{array}$ \\
\hline Female & $\begin{array}{l}-0.5136 \\
(-19.23)\end{array}$ & $\begin{array}{l}-0.2774 \\
(-15.46)\end{array}$ & $\begin{array}{l}-0.3775 \\
(-24.17)\end{array}$ & $\begin{array}{r}-0.3512 \\
(-9.64)\end{array}$ & $\begin{array}{r}-0.2210 \\
(-3.25)\end{array}$ & $\begin{array}{r}-0.3320 \\
(-9.99)\end{array}$ \\
\hline \# of individuals & 3,270 & 4,242 & 6,949 & 3,355 & 674 & 3,740 \\
\hline \# of observations & 11,439 & 13,490 & 25,379 & 13,252 & 1,784 & 15,036 \\
\hline
\end{tabular}

Source: Own computations based on the ECHP. 
Table 7: Estimates of household head's labour income uncertainty by selected groups

\begin{tabular}{|c|c|c|c|c|c|c|c|c|c|c|c|c|c|c|c|c|}
\hline & \multicolumn{8}{|c|}{ Income uncertainty and skewness based on residuals equation (7) } & \multicolumn{8}{|c|}{ Income uncertainty based on $\mathrm{CV}$ and $\mathrm{K}$ on yearly income } \\
\hline & \multicolumn{4}{|c|}{ Germany } & \multicolumn{4}{|c|}{ Spain } & \multicolumn{4}{|c|}{ Germany } & \multicolumn{4}{|c|}{ Spain } \\
\hline & \multicolumn{2}{|c|}{ Owners } & \multicolumn{2}{|c|}{ Renters } & \multicolumn{2}{|c|}{ Owners } & \multicolumn{2}{|c|}{ Renters } & \multicolumn{2}{|c|}{ Owners } & \multicolumn{2}{|c|}{ Renters } & \multicolumn{2}{|c|}{ Owners } & \multicolumn{2}{|c|}{ Renters } \\
\hline & Mean & S.D. & Mean & S.D. & Mean & S.D. & Mean & S.D. & Mean & S.D. & Mean & S.D. & Mean & S.D. & Mean & S.D. \\
\hline $\begin{array}{l}\text { Total } \\
\text { Age group }\end{array}$ & 0.188 & 0.253 & 0.255 & 0.402 & 0.336 & 0.330 & 0.384 & 0.402 & 0.222 & 0.239 & 0.261 & 0.270 & 0.290 & 0.258 & 0.364 & 0.311 \\
\hline 25 to 35 & 0.172 & 0.192 & 0.298 & 0.481 & 0.342 & 0.348 & 0.476 & 0.535 & 0.261 & 0.268 & 0.293 & 0.285 & 0.292 & 0.287 & 0.333 & 0.314 \\
\hline 35 to 45 & 0.204 & 0.265 & 0.254 & 0.372 & 0.338 & 0.316 & 0.295 & 0.238 & 0.210 & 0.216 & 0.239 & 0.254 & 0.291 & 0.240 & 0.351 & 0.322 \\
\hline 45 to 55 & 0.189 & 0.327 & 0.210 & 0.287 & 0.354 & 0.354 & 0.398 & 0.391 & 0.178 & 0.232 & 0.208 & 0.239 & 0.294 & 0.255 & 0.372 & 0.277 \\
\hline 55 to 65 & 0.151 & 0.219 & 0.196 & 0.375 & 0.214 & 0.147 & 0.263 & 0.266 & 0.203 & 0.237 & 0.254 & 0.249 & 0.185 & 0.133 & 0.417 & 0.324 \\
\hline \multicolumn{17}{|l|}{$\frac{\text { Sector of }}{\text { emplovmen }}$} \\
\hline Private & 0.205 & 0.267 & 0.265 & 0.384 & 0.383 & 0.361 & 0.437 & 0.443 & 0.245 & 0.249 & 0.276 & 0.274 & 0.334 & 0.270 & 0.418 & 0.319 \\
\hline Public & 0.144 & 0.209 & 0.223 & 0.407 & 0.197 & 0.147 & 0.232 & 0.184 & 0.153 & 0.196 & 0.203 & 0.249 & 0.148 & 0.142 & 0.162 & 0.167 \\
\hline \multicolumn{17}{|l|}{$\frac{\text { Unemploved. }}{\text { after } 1989}$} \\
\hline No & 0.172 & 0.245 & 0.214 & 0.346 & 0.294 & 0.295 & 0.319 & 0.412 & 0.186 & 0.212 & 0.209 & 0.249 & 0.241 & 0.238 & 0.252 & 0.258 \\
\hline Yes & 0.239 & 0.273 & 0.329 & 0.480 & 0.392 & 0.366 & 0.462 & 0.379 & 0.327 & 0.281 & 0.349 & 0.283 & 0.349 & 0.270 & 0.456 & 0.322 \\
\hline \multicolumn{17}{|l|}{ Marital status } \\
\hline Not married & 0.166 & 0.187 & 0.264 & 0.352 & 0.334 & 0.339 & 0.413 & 0.510 & 0.198 & 0.203 & 0.280 & 0.283 & 0.307 & 0.287 & 0.399 & 0.355 \\
\hline Married & 0.193 & 0.266 & 0.248 & 0.433 & 0.336 & 0.330 & 0.366 & 0.322 & 0.227 & 0.246 & 0.248 & 0.260 & 0.287 & 0.253 & 0.341 & 0.277 \\
\hline \multicolumn{17}{|l|}{$\frac{\text { Household }}{\text { twno }}$} \\
\hline type & & & & & & & & & & & & & & & & \\
\hline Single & 0.168 & 0.208 & 0.239 & 0.348 & 0.281 & 0.210 & 0.346 & 0.487 & 0.191 & 0.211 & 0.246 & 0.262 & 0.243 & 0.195 & 0.403 & 0.399 \\
\hline Single w. kids & 0.122 & 0.067 & 0.299 & 0.372 & 0.368 & 0.289 & 0.304 & 0.195 & 0.183 & 0.222 & 0.346 & 0.325 & 0.291 & 0.231 & 0.341 & 0.284 \\
\hline Couple & 0.177 & 0.226 & 0.251 & 0.346 & 0.365 & 0.456 & 0.408 & 0.500 & 0.163 & 0.179 & 0.266 & 0.274 & 0.311 & 0.326 & 0.293 & 0.256 \\
\hline Couple w. kids & 0.196 & 0.272 & 0.258 & 0.466 & 0.331 & 0.309 & 0.418 & 0.364 & 0.244 & 0.257 & 0.250 & 0.262 & 0.290 & 0.253 & 0.372 & 0.293 \\
\hline
\end{tabular}

Source: Own computations based on the ECHP. 
Table 8: Estimates of household head's labour income uncertainty by selected groups

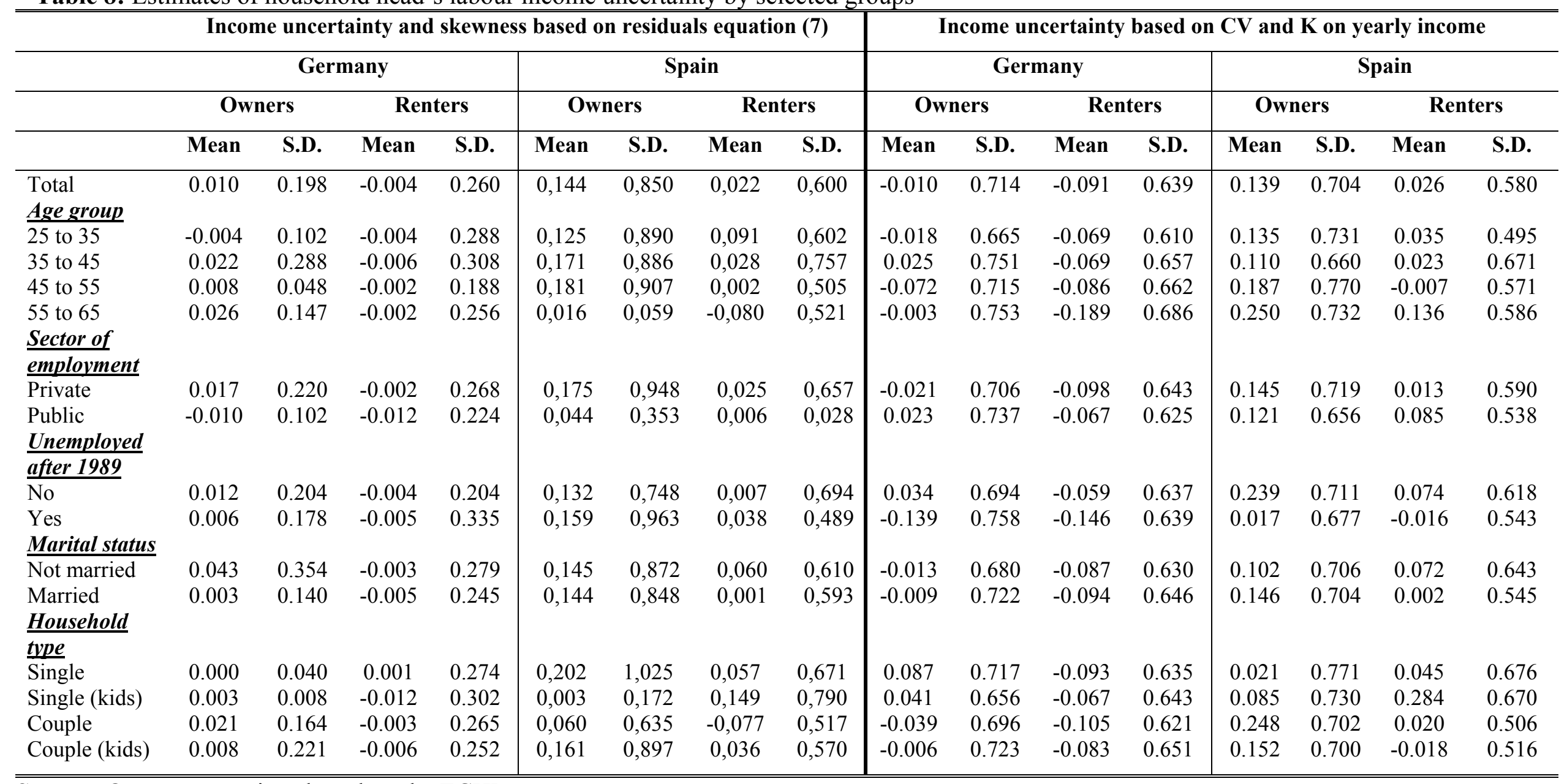

Source: Own computations based on the ECHP. 
Table 9: Probit with robust standard error estimates of the housing tenure choice equation (6).

\begin{tabular}{|c|c|c|c|c|c|c|c|c|}
\hline & \multicolumn{4}{|c|}{ Germany } & \multicolumn{4}{|c|}{ Spain } \\
\hline & (1) & (2) & (3) & (4) & (1) & (2) & (3) & (4) \\
\hline Cosntant & $\begin{array}{r}-5.1233 \\
(-6.97)\end{array}$ & $\begin{array}{r}-5.0171 \\
(-6.86)\end{array}$ & $\begin{array}{r}-3.7191 \\
(-6.83)\end{array}$ & $\begin{array}{r}-3.7048 \\
(-6.66)\end{array}$ & $\begin{array}{r}-1.4037 \\
(-1.44)\end{array}$ & $\begin{array}{r}-1.6173 \\
(-1.56)\end{array}$ & $\begin{array}{r}0.5580 \\
(0.55)\end{array}$ & $\begin{array}{r}0.4789 \\
(0.46)\end{array}$ \\
\hline \multicolumn{9}{|l|}{$\underline{\text { H. Head labour income }}$} \\
\hline Income uncertainty & $\begin{array}{r}-0.6955 \\
(-3.76) \\
-0.1162\end{array}$ & $\begin{array}{r}-0.9487 \\
(-4.31) \\
-0.1565\end{array}$ & $\begin{array}{r}-0.1815 \\
(-1.65) \\
-0.0284\end{array}$ & $\begin{array}{r}-0.1981 \\
(-1.75) \\
-0.0309\end{array}$ & $\begin{array}{r}-0.6775 \\
(-2.99) \\
-0.2634\end{array}$ & $\begin{array}{r}-0.9163 \\
(-3.35) \\
-0.3571\end{array}$ & $\begin{array}{r}-0.4526 \\
(-2.43) \\
-0.1795\end{array}$ & $\begin{array}{r}-0.5161 \\
(-2.76) \\
-0.2047\end{array}$ \\
\hline Income skewness & & $\begin{array}{r}0.2232 \\
(3.04) \\
0.0368\end{array}$ & & $\begin{array}{r}0.0751 \\
(1.87) \\
0.0117\end{array}$ & & $\begin{array}{r}0.2238 \\
(1.87) \\
0.0872\end{array}$ & & $\begin{array}{r}0.1906 \\
(2.48) \\
0.0756\end{array}$ \\
\hline Transitory income & $\begin{array}{r}0.9384 \\
(3.14) \\
0.1567\end{array}$ & $\begin{array}{r}1.4999 \\
(2.91) \\
0.2474\end{array}$ & & & $\begin{array}{r}0.8909 \\
(1.72) \\
0.3464\end{array}$ & $\begin{array}{r}1.2747 \\
(2.10) \\
0.4968\end{array}$ & & \\
\hline Permanent income/1000 & $\begin{array}{r}0.0308 \\
(8.05) \\
0.0051\end{array}$ & $\begin{array}{r}0.0301 \\
(7.79) \\
0.0050\end{array}$ & & & $\begin{array}{r}0.0001 \\
(1.77) \\
2.5 \cdot 10^{-5}\end{array}$ & $\begin{array}{r}0.0001 \\
(1.65) \\
2.3 \cdot 10^{-5}\end{array}$ & & \\
\hline $\begin{array}{l}\text { Average negative shocks greater } \\
\text { than average positive shocks (TI2) }\end{array}$ & $\begin{array}{r}-0.2065 \\
(-3.07) \\
-0.0326\end{array}$ & $\begin{array}{r}-0.2177 \\
(-3.11) \\
-0.0338\end{array}$ & & & $\begin{array}{r}-0.5518 \\
(-2.05) \\
-0.2173\end{array}$ & $\begin{array}{r}-0.6205 \\
(-2.27) \\
-0.2432\end{array}$ & & \\
\hline Yearly income/1000 & & & $\begin{array}{r}0.0061 \\
(6.70) \\
0.0009\end{array}$ & $\begin{array}{r}0.0060 \\
(4.95) \\
0.0009\end{array}$ & & & $\begin{array}{r}0.0001 \\
(2.86) \\
4.0 \cdot 10^{-5}\end{array}$ & $\begin{array}{r}0.0001 \\
(2.74) \\
3.9 \cdot 10^{-5}\end{array}$ \\
\hline \multicolumn{9}{|l|}{$\underline{\text { H. Head characteristics }}$} \\
\hline (Married) & $\begin{array}{r}0.3313 \\
(3.81) \\
0.0525\end{array}$ & $\begin{array}{r}0.3352 \\
(3.85) \\
0.0525\end{array}$ & $\begin{array}{r}0.4114 \\
(5.38) \\
0.0605\end{array}$ & $\begin{array}{r}0.4117 \\
(5.40) \\
0.0603\end{array}$ & $\begin{array}{r}0.5238 \\
(3.37) \\
0.2059\end{array}$ & $\begin{array}{r}0.5314 \\
(3.37) \\
0.2091\end{array}$ & $\begin{array}{r}0.5658 \\
(4.09) \\
0.2226\end{array}$ & $\begin{array}{r}0.5871 \\
(3.66) \\
0.2307\end{array}$ \\
\hline (Age) & $\begin{array}{r}0.0542 \\
(1.84) \\
0.0091\end{array}$ & $\begin{array}{r}0.0506 \\
(1.70) \\
0.0083\end{array}$ & $\begin{array}{r}0.0704 \\
(3.07) \\
0.0110\end{array}$ & $\begin{array}{r}0.0698 \\
(2.92) \\
0.0109\end{array}$ & $\begin{array}{r}0.0801 \\
(1.65) \\
0.0311\end{array}$ & $\begin{array}{r}0.0730 \\
(1.49) \\
0.0285\end{array}$ & $\begin{array}{r}0.0179 \\
(0.42) \\
0.0071\end{array}$ & $\begin{array}{r}0.0192 \\
(0.45) \\
0.0076\end{array}$ \\
\hline Age squared & $\begin{array}{r}-0.0007 \\
(-2.20) \\
-0.0001\end{array}$ & $\begin{array}{r}-0.0007 \\
(-2.1) \\
-0.0001\end{array}$ & $\begin{array}{r}-0.0009^{*} \\
(-3.38) \\
-0.0001\end{array}$ & $\begin{array}{r}-0.0009 \\
(-3.17) \\
-0.0001\end{array}$ & $\begin{array}{r}-0.0011 \\
(-2.07) \\
-0.0004\end{array}$ & $\begin{array}{r}-0.0010 \\
(-1.89) \\
-0.0004\end{array}$ & $\begin{array}{r}0.0179 \\
(0.42) \\
-0.0002\end{array}$ & $\begin{array}{r}-0.0004 \\
(-0.93) \\
-0.0002\end{array}$ \\
\hline \multicolumn{9}{|l|}{$\underline{\text { H. Head emplovment }}$} \\
\hline $\begin{array}{l}\text { Unemployed after } 1989 \\
\text { (Unemp89) }\end{array}$ & $\begin{array}{r}-0.1863 \\
(-2.65) \\
-0.0299\end{array}$ & $\begin{array}{r}-0.1682 \\
(-2.37) \\
-0.0267\end{array}$ & $\begin{array}{r}-0.2732 \\
(-4.41) \\
-0.0405\end{array}$ & $\begin{array}{r}-0.2634 \\
(-4.21) \\
-0.0390\end{array}$ & $\begin{array}{r}-0.0647 \\
(-1.80) \\
-0.0250\end{array}$ & $\begin{array}{r}-0.0607 \\
(-1.69) \\
-0.0237\end{array}$ & $\begin{array}{r}-0.2671 \\
(-2.26) \\
-0.1057\end{array}$ & $\begin{array}{r}-0.2396 \\
(-2.01) \\
-0.0948\end{array}$ \\
\hline $\begin{array}{l}\text { Long term unemp. After } 1989 \\
\text { (Longun89) }\end{array}$ & $\begin{array}{r}-0.2740 \\
(-3.06) \\
-0.0406\end{array}$ & $\begin{array}{r}-0.2862 \\
(-3.16) \\
-0.0416\end{array}$ & $\begin{array}{r}-0.2051 \\
(-2.52) \\
-0.0291\end{array}$ & $\begin{array}{r}-0.2119 \\
(-2.62) \\
-0.0299\end{array}$ & $\begin{array}{r}-0.2802 \\
(-1.89) \\
-0.1103\end{array}$ & $\begin{array}{r}-0.2743 \\
(-1.87) \\
-0.1256\end{array}$ & $\begin{array}{r}-0.2734 \\
(-1.84) \\
-0.1087\end{array}$ & $\begin{array}{r}-0.2938 \\
(-1.98) \\
-0.1168\end{array}$ \\
\hline $\begin{array}{l}\text { Public worker } \\
\text { (Public) }\end{array}$ & $\begin{array}{r}0.1271 \\
(1.86) \\
0.0221 \\
\end{array}$ & $\begin{array}{r}0.1296 \\
(1.88) \\
0.0223 \\
\end{array}$ & $\begin{array}{r}0.1547 \\
(2.46) \\
0.0257 \\
\end{array}$ & $\begin{array}{r}0.1538 \\
(2.47) \\
0.0255\end{array}$ & $\begin{array}{r}0.0726 \\
(0.56) \\
0.0281 \\
\end{array}$ & $\begin{array}{r}0.0749 \\
(0.57) \\
0.0290 \\
\end{array}$ & $\begin{array}{r}0.0992 \\
(0.78) \\
0.0392 \\
\end{array}$ & $\begin{array}{r}0.0903 \\
(0.71) \\
0.0357 \\
\end{array}$ \\
\hline
\end{tabular}


Table 9: Continuation

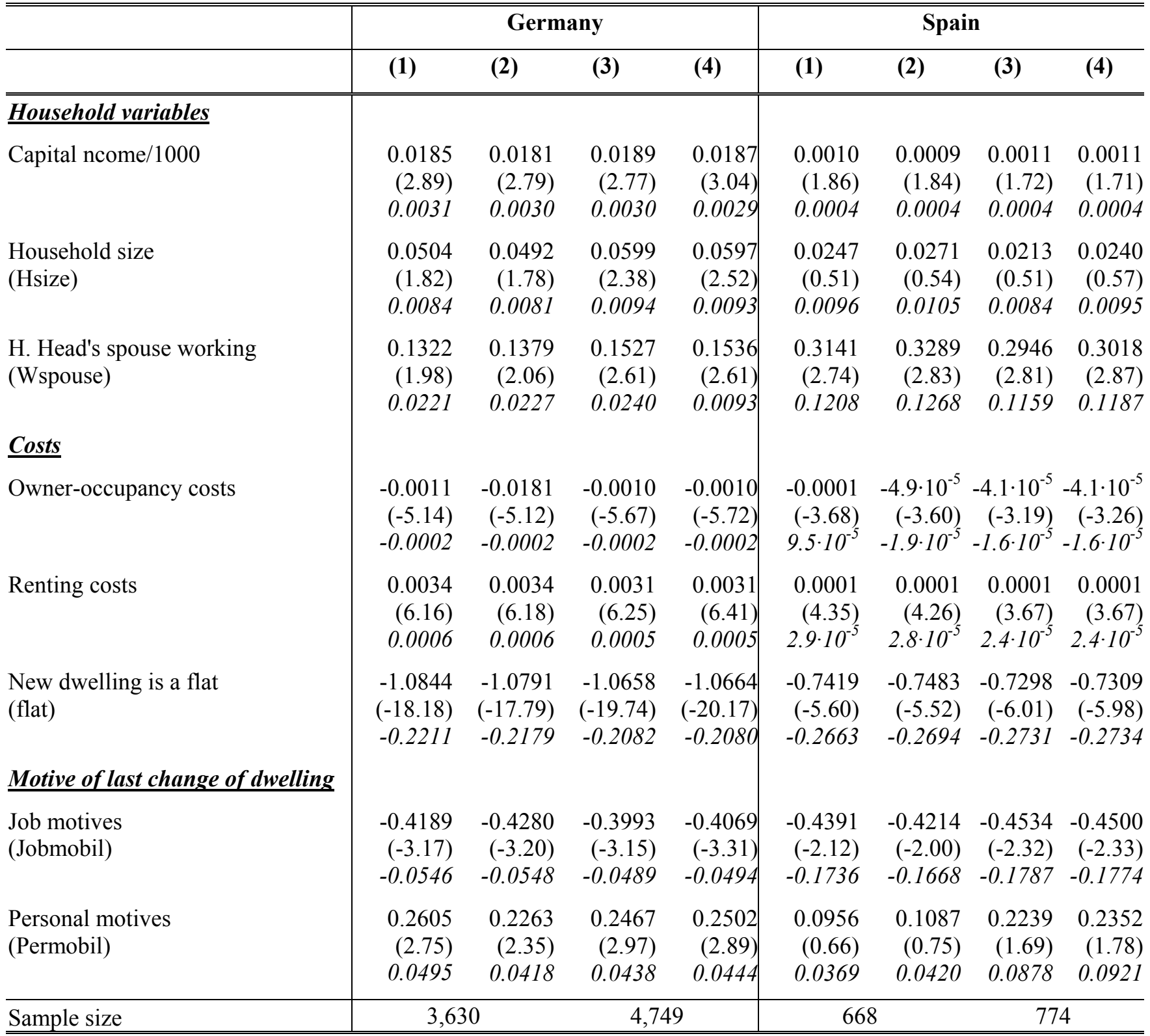

Source: Own computations based on the ECHP.

Notes: Endogenous variable: 1 if owner, 0 if renter.

Columns (1) and (2): Uncertainty, skewness, transitory and permanent labour income estimated from income equation (7), and measured as (8) to (11).

Columns (3) and (4): Uncertainty and skewness measured as the CV and $\mathrm{K}$.

Z-values in parenthesis; elasticities in italic font.

The names in parenthesis refer to the variables defined in table 4. 